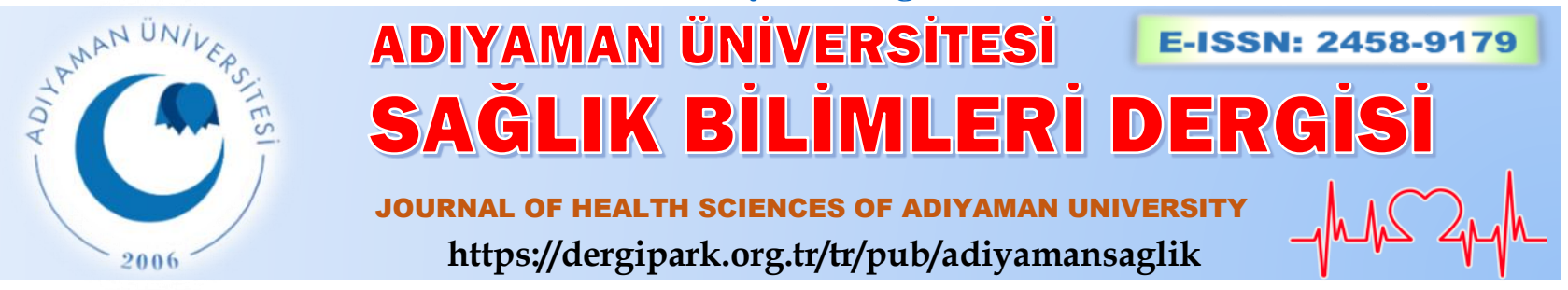

Özgün Araştırma/Research Article

\title{
Aspartam ve asesülfam $K$ kullanımının testis yapısına etkilerinin ince yapı düzeyinde incelenmesi
}

\section{Ultrastructural examination of the effects aspartame and acesulfame $K$ on testis structure}

\author{
Leman SENCAR 1 @(D), Yurdun KUYUCU ${ }^{1}$ \\ ${ }^{1}$ Çukurova Üniversitesi, Tıp Fakültesi, Histoloji ve Embriyoloji Anabilim Dalı, 01250, Adana-Türkiye
}

Atıf gösterme/Cite this article as: Sencar L, Kuyucu Y. Aspartam ve asesülfam K kullanımının testis yapısına etkilerinin ince yap1 düzeyinde incelenmesi. ADYÜ Sağlık Bilimleri Derg. 2020;6(3):320-331. doi:10.30569.adiyamansaglik.789927

Öz

Amaç: Bu çalışma, ülkemizde ve dünyada yaygın olarak kullanılan aspartam ve asesülfam K'nın, sıçanlarda testis dokuları üzerindeki etkilerinin $1 s ̧ 1 \mathrm{k}$ ve elektron mikroskobik düzeyde araştırılması amacıyla yapılmıştır.

Gereç ve Yöntem: Çalışmada 60 adet erkek sıçan kullanıldı ve bu denekler rastgele olarak 6 eşit gruba ayrıld1. 1. gruptaki hayvanlar kontrol grubu olarak değerlendirildi; 2.gruptaki hayvanlara $200 \mathrm{mg} / \mathrm{kg} /$ gün aspartam; 3.gruptaki hayvanlara $300 \mathrm{mg} / \mathrm{kg} / \mathrm{gün}$ aspartam; 4. gruptaki hayvanlara $300 \mathrm{mg} / \mathrm{kg} / \mathrm{gün}$ asesülfam K; 5. gruptaki hayvanlara $600 \mathrm{mg} / \mathrm{kg} / \mathrm{gün}$ asesülfam $K$ ve son gruba da $300 \mathrm{mg} / \mathrm{kg} / \mathrm{gün}$ aspartam $+300 \mathrm{mg} / \mathrm{kg} /$ gün asesülfam $\mathrm{K}$ birlikte 8 hafta süreyle verildi. 8. haftanın sonunda deneklerden testis dokuları alındı ve dokular 1 şık ve elektron mikroskobik olarak değerlendirildi.

Bulgular: Aspartam ve asesülfam K kullanımının testis dokusunda dejenerasyona yol açtığı ve spermatogenez sürecinde sağlıklı spermatid oluşumunu engellediği izlendi.

Sonuç: Aspartam ve asesülfam K tüketiminin erkek sıçanlarda testis dejenerasyonuna neden olduğu görüldü. Bununla birlikte, erkek üreme sistemindeki aspartam ve asesülfam $\mathrm{K}$ toksisitesinin doğrulanması için daha kapsamlı çalışmaların yapılması gerektiği kanaatine varıld1.

Anahtar Kelimeler: Asesülfam K; Aspartam; Elektron mikroskop; Işık mikroskop; Testis.

\begin{abstract}
Aim: The present study was carried out to investigate the effects of aspartame and acesulfame K, which are widely used in our country and the world, on testicular tissues in rats at light and electron microscopic level.

Materials and Methods: In this experimental study, 60 male rats were used. The experimental animals were randomly divided into 6 equal groups. Animals in group 1 were considered as control group; Animals in group 2 received $200 \mathrm{mg} / \mathrm{kg} /$ day of aspartame; Group 3 animals received $300 \mathrm{mg} / \mathrm{kg} /$ day aspartame; Animals in group 4 received acesulfame $\mathrm{K}$ at $300 \mathrm{mg} \mathrm{kg} / \mathrm{day}$; The animals in the 5th group were given acesulfame K 600 $\mathrm{mg} / \mathrm{kg} /$ day and the last group received $300 \mathrm{mg} / \mathrm{kg} /$ day aspartame $+300 \mathrm{mg} / \mathrm{kg} /$ day acesulfame $\mathrm{K}$ for 8 weeks. At the end of the 8th week, testicular tissue samples obtained from rats were examined by light and electron microscopic methods.
\end{abstract}

Results: It has been observed that the use of aspartame and acesulfame $\mathrm{K}$ causes degeneration in the testicular tissue depending on the döşe and it has been observed that prevents the formation of healthy spermatids during the spermatogenesis process.

Conclusion: The findings of the present study elucidated that consumption of aspartame and acesulfame $\mathrm{K}$ resulted in testis damages in mice. Confirmation of the toxicity of aspartame in male reproductive system requires more extensive experimental studies and clinical trials.

Keywords: Acesulfame K; Aspartame; Electron microscope; Light microscope; Testis.

Yazışma Adresi/Address for Correspondence: Leman SENCAR, Çukurova Üniversitesi, Tıp Fakültesi, Histoloji ve Embriyoloji Anabilim Dal1, 01250, Adana-Türkiye, E-mail: 1sencar@cu.edu.tr 


\section{Giriş}

Besleyici olmayan yapay tatlandırıcılar, yiyecek ve içecek lezzetini azaltmadan kalori alımında azalmaya izin veren düşük enerjili şekerlerdir. Sukraloz, ASP (aspartam), sakarin ve AceK (asesülfam-K) içecekleri tatlandırmak için sıklıkla kullanılan tatlandırıcılardır. ${ }^{1}$ Kalori alımını azaltmak amaciyla, 1980'lerde, ABD'de düşük kalorili tatlandırıcı tüketimi belirgin şekilde artmıştır. ${ }^{2}$

Birleşik Devletler ve Avrupa Birliği tavsiyelerine göre kabul edilebilir günlük aspartam alımı, sırasiyla $50 \mathrm{mg} / \mathrm{kg}$ ve 40 $\mathrm{mg} / \mathrm{kg}^{\prime} \mathrm{d} ı{ }^{3,4} \quad$ Yapay tatlandırıciların tüketiminin kabul edilebilir günlük alım aralığında güvenli olduğu düşünülse de bazı deneysel ve epidemiyolojik çalışmaların sonuçları, yapay tatlandırıcı tüketiminin obezite, metabolik sendrom, bağırsak mikrobiyotasında değişiklik, kanser gibi sağlık üzerinde bazı olumsuz etkilere neden olabileceğini göstermiştir. ${ }^{5}$

Besleyici olmayan yapay tatlandırıcılar, alınan kalori miktarını azaltırken lezzeti arttırmak için gıdalardaki sükrozun yerini büyük ölçüde alsalar da insan sağlı̆̆ üzerindeki etkileri tartışmalıdır. Son yıllarda yapılan bazı araştırmalarda Aspartam kullanımının hepatotoksisite ve kanser gibi hastalıklarla ilişkisi olabileceği bildirilmiştir. Aspartamın sıçan karaciğerinde onkogenlerin ekspresyonunda dikkat çekici değişikliklere neden olduğu da gösterilmiştir. Literatürde bu konu ile ilgili tartışmaya açık bilgiler bulunmakla birlikte tatlandırıcıların kanser riskindeki rolü geniş çapta araştırılmaktadır. ${ }^{6}$

Aspartamın yaklaşık \%50'si fenilalanin, $\% 40$ '1 aspartik asit ve \%10'u metanoldür. Metanolün beyinde toksik etkiye sahip olduğu bilinmektedir. Ayrıca, aspartam tarafindan salınan metanolün beyinde, lokomotor fonksiyonlarda değişikliğe sebep olabileceği bildirilmiştir. $^{7}$

Aspartam tarafindan salınan metanol, doku ve hücreler üzerinde oksidatif stres oluşturmaktadır. Oksidatif stres, sperm fonksiyonu ve kalitesinin etiyolojisinde de önemli bir role sahiptir. ${ }^{7}$ Diğer taraftan günümüzde oldukça yaygın hale gelen erkek infertilisinde yapay tatlandırıcı kullanımının rolünün bulunup bulunmadığı tam açık değildir. Bugüne kadar yapılan çalışmalarda, yapay tatlandırıcıların çeşitli doku ve organlarda in vivo ve in vitro etkileri rapor edilmesine rağmen, hücresel yapının nasıl etkilendiğine dair bir çalışmaya literatürde rastlanmamıştır. $\mathrm{Bu}$ çalışmada, ülkemizde ve dünyada yaygın olarak kullanılan aspartam ve asesülfam K'nın, sıçanlarda testis dokuları üzerindeki etkilerinin 1 ş1k ve elektron mikroskobik düzeyde araştırılması amaçlanmıştır.

\section{Gereç ve Yöntem}

\section{Araştırmanın tipi}

Araştırma özgün deneysel bir araştırmadır.

\section{Hayvanlarm temini}

Aspartam ve asesülfam K'nın, sıçanların testis dokuları üzerindeki etkilerinin 1 şık ve elektron mikroskobik düzeyde araştırılması amaciyla Çukurova Üniversitesi Sağlik Bilimleri Deneysel Tıp Araştırma ve Uygulama Merkezinden 250-300 gr ağırlığında 60 adet erkek Wistar cinsi siçan temin edildi. Deney hayvanları rastgele olarak 6 eşit gruba ayrıldı. Kullanılan yapay tatlandırıcılar distile su içerisinde çözülerek oral yolla deneklere uygulandi. Alkafafy ve arkadaşlarının yaptıkları çalışmada Aspartamın $250 \mathrm{mg} / \mathrm{kg} /$ gün dozda toksik etkiye sahip olduğu gösterilmiştir. ${ }^{6}$ Aspartam ve asesülfam $\mathrm{K}$ iki farklı sınıf yapay tatlandırıcı olup birçok üründe birlikte bulunmaktadır. $\mathrm{Bu}$ nedenle çalışmamızda Mukhopadhyay ve arkadaşlarının ${ }^{8}$ çalışmasına benzer olarak, bu iki farklı türde tatlandırıcının sinerjik etkilerini gösterebilmek amaciyla gruplardan birine bu tatlandırıcıların birlikte verilmesini planladik. Çalışmamızda aspartam ve asesülfam K'nın toksik etki oluşturabilecek dozları kullanılmıştır. Buradan yola çıkarak, 1. gruptaki hayvanlar kontrol grubu olarak değerlendirildi ve bu gruba normal beslenmeye ilaveten günde $5 \mathrm{ml}$ distile su; 2 . Gruptaki hayvanlara $200 \mathrm{mg} / \mathrm{kg} /$ gün aspartam; 3.gruptaki hayvanlara 300 $\mathrm{mg} / \mathrm{kg} /$ gün aspartam verildi. 4. gruptaki hayvanlara $300 \mathrm{mg} / \mathrm{kg} / \mathrm{gün}$ asesülfam $\mathrm{K}$; 5 . gruptaki hayvanlara $600 \mathrm{mg} / \mathrm{kg} / \mathrm{gün}$ asesülfam $\mathrm{K}$ ve son gruba da $300 \mathrm{mg} / \mathrm{kg} /$ gün 
aspartam+300 $\mathrm{mg} / \mathrm{kg} /$ gün asesülfam $\mathrm{K}$ birlikte 8 hafta süreyle verildi. Deney süresince hayvanlar, normal sıçan yemi ile beslendi. Çalışma öncesinde ilgili üniversitenin Sağlık Bilimleri Deneysel Araştırma Merkezi'nden hayvan deneyleri yerel etik kurul onayı alınmıştır. (Tarih: 08.02.2009: no:4)

\section{Perfüzyon ve dokuların alınması}

8. haftanın sonunda denekler, kardiyak perfüzyonla sakrifiye edildi ve testis doku parçaları alındı. Işık ve elektron mikroskobik incelemeler için hazırlandi.

\section{Işık mikroskobi yöntemleri}

Iş1k mikroskobik incelemeler için tüm gruplardaki sıçanlardan elde edilen testis doku örnekleri, \%10'luk formaldehit içerisine alındı ve oda 1sısında 48-72 saat süreyle tespit edildi. Daha sonra formaldehitin uzaklaştırılması için dokular su ile yıkandı ve Leica TP 1020 Ototeknikon Cihazı ile doku takibi yapıldı. Bloklama işlemini takiben mikrotom ile $5 \mu \mathrm{m}$ kalınlığında alınan histolojik kesitler Hematoksilen-Eozin (H\&E) ile boyand. Olimpus BX53 1şık mikroskobunda incelenerek fotoğrafland.

\section{Elektron mikroskobi yöntemleri}

Elektron mikroskobik değerlendirme için alınan testis doku parçaları Millonig fosfat tamponu ile hazırlanmış \%5 lik gluteraldehit solüsyonunda 4 saat kadar tespit edildi. Daha sonra dokular 2 defa Millonig fosfat tamponunda $10 \mathrm{dk}$ çalkalandı. Ardından
Millonig fosfat tamponu ile hazırlanmış \%1 lik osmium tetraoksit solüsyonu ile ikinci defa tespit edildi ve yine fosfat tamponu ile iki kez 10 'ar dk yıkandı. Dokular daha sonra artan alkol serilerinden geçirilerek dehidrate edildi. Dehidrate edilen doku parçaları propilen oksit içerisinde immerse edildi. $\mathrm{Bu}$ işlemlerden sonra doku parçaları, içerisinde yeni hazırlanmış gömme materyali (rezin) bulunan tüplere alındı ve bir gece süreyle rotatorda karıştırıldı.

Ertesi gün doku parçaları taze hazırlanmış gömme materyali kullanılarak polietilen kapsüllere gömüldü ve $60^{\circ} \mathrm{C}$ etüvde 48 saat süreyle polimerize edildi. Bloklardan Reichert Ultracut S ultramikrotomu ile $500 \quad \mathrm{~A}^{\mathrm{o}}$ kalınlığında kesitler alındı. Kesitler 200-300 gözenekli bakır gridlere toplandı ve \%70'lik etil alkolde doymuş uranil asetat ve kurşun sitrat solüsyonları ile boyand. Boyanan kesitler JEOL-JEM 1400 Transmisyon Elektron Mikroskobu (Japan) ile incelendi ve mikrograflar elde edildi.

\section{Bulgular}

\section{Işık mikroskobik bulgular}

Kontrol grubuna ait testis doku kesitlerinin 1ş1k mikroskobik incelemesinde, testis parankimasının, dıştan tunika albuginea ile sarılı olduğu ve çok sayıda seminiferöz tübüller ile interstisyumdan oluştuğu görüldü. Membrana propria ile desteklenmiş seminiferöz tübüller, spermatojenik hücreler ve Sertoli hücrelerinden oluşmaktaydı (Şekil $1)$.

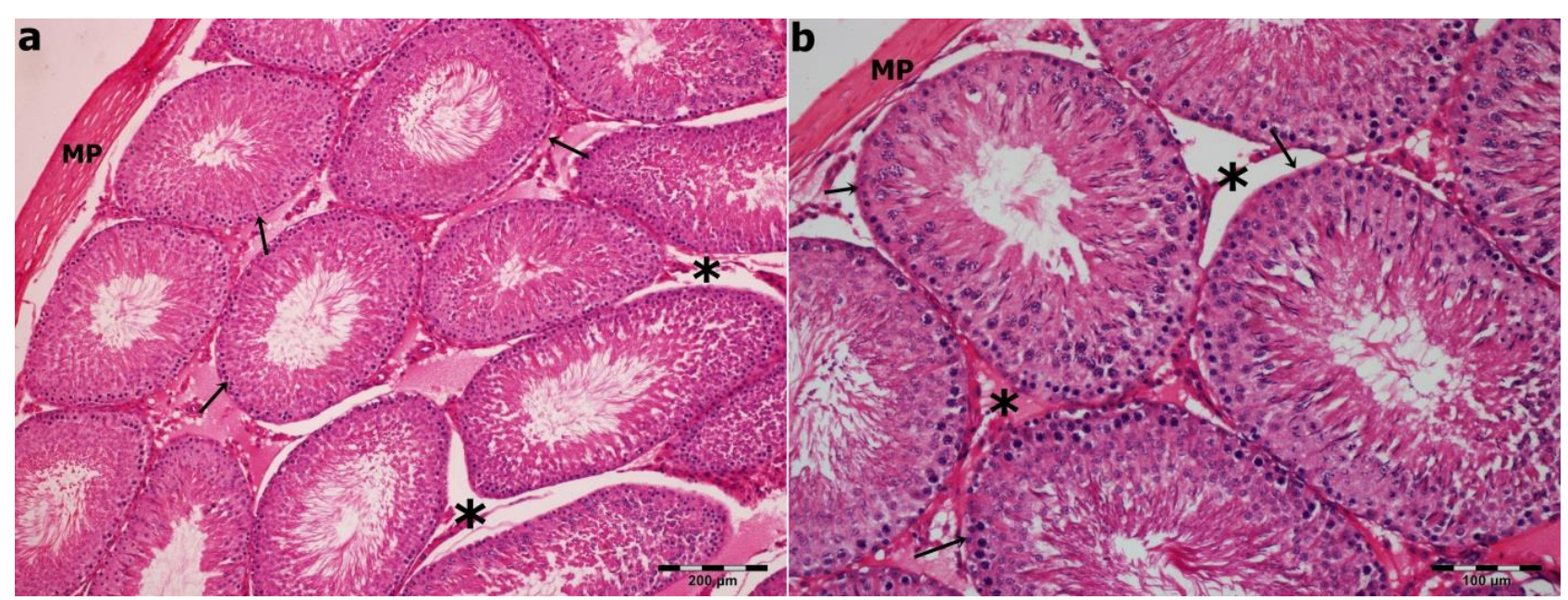

Şekil 1. Kontrol grubuna ait testis dokularının 1şık mikroskobik görünümü. Normal görünümlü membrana propria (MP), seminiferöz tübüller (oklar) ve interstisyel alanlar (*) izlenmektedir. H\&E. a) Bar: $200 \mu \mathrm{m}$. b) Bar: $100 \mu \mathrm{m}$ 
$200 \mathrm{mg} / \mathrm{kg} /$ gün aspartam uygulanan sıçanların testis dokularının 1şık mikroskobik incelemesinde, seminiferöz tübüllerde dejeneratif alanların olduğu görüldü. İnterstisyel alanda yer alan Leydig hücre sayısında azalma olduğu izlendi (Şekil $2 \mathrm{a}$ ve $2 b)$.

$300 \mathrm{mg} / \mathrm{kg} /$ gün aspartam uygulanan sıçanların testis dokularının 1şık mikroskobik incelemesinde, seminiferöz tübül epitelinde dejenerasyon ve dökülmelerin olduğu, bazı tübüllerin vakuolize görünüm aldığı görüldü. Ayrıca birçok tübülün lümeninde immatur spermatojenik hücre birikimine rastland. Membrana propriada kalınlaşma ve düzensizlik dikkati çekti. İnsterstisyel alanda genişleme ve ödem belirgindi (Şekil 2c ve 2d).
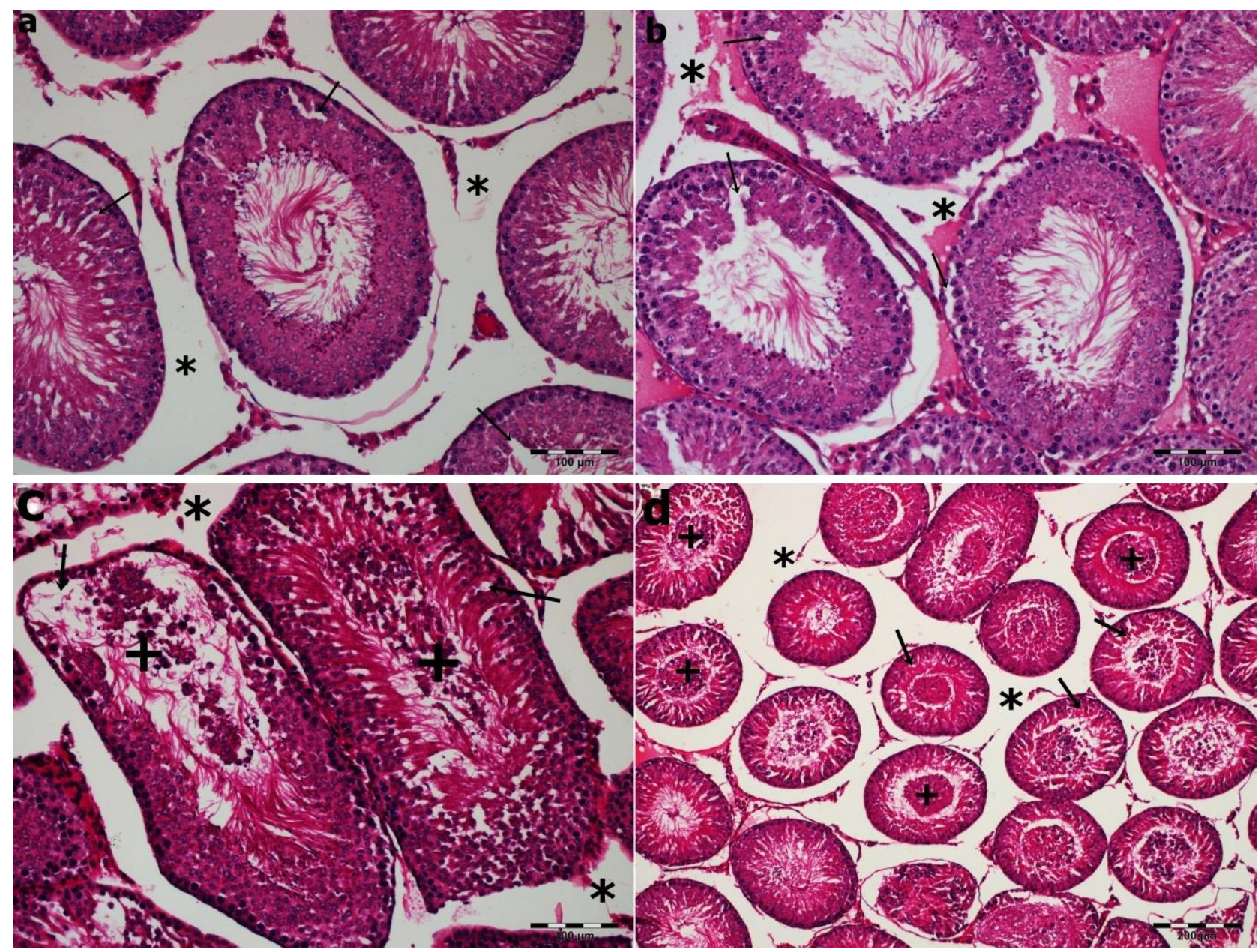

Şekil 2. (a-b) $200 \mathrm{mg} / \mathrm{kg} /$ gün aspartam uygulanan sıçanların testis dokularının ışık mikroskobik görünümü. a) Seminiferöz tübül epitelinde hafif dejenerasyon (oklar) ve insterstisyel ödem (*) görülmektedir. H\&E. Bar: $100 \mu \mathrm{m} . \mathrm{b}$ ) Seminiferöz tübüller (oklar) ve insterstisyal alan $\left({ }^{*}\right)$ görülmektedir. H\&E. Bar: $100 \mu \mathrm{m}$. (c-d) $300 \mathrm{mg} / \mathrm{kg} / \mathrm{gün}$ aspartam uygulanan sıçanların testis doku örneklerinin ıșı mikroskobik görünümü. c) Seminiferöz tübüllerde dejenerasyon (oklar), tübül lümenlerinde immatur hücre birikimi $(+)$ ve insterstisyal ödem $\left(^{*}\right)$ devam etmektedir. H\&E. Bar: $50 \mu \mathrm{m}$. d) Seminiferöz tübül epitelinde dejenerasyon (oklar), tübül lümenlerinde immatur hücre birikimi $(+)$ ve insterstisyal ödem (*) görülmektedir. H\&E. Bar: $100 \mu \mathrm{m}$.

$300 \mathrm{mg} / \mathrm{kg} /$ gün asesülfam $\mathrm{K}$ uygulanan sıçanların testis dokularının 1şık mikroskobik incelemesinde, seminiferöz tübüller ve insterstisyumun normal görünümde olduğu izlendi. Leydig hücrelerinin yap1 ve dağılımlarının kontrol grubuna benzer şekilde normal olduğu görüldü (Şekil 3a ve 3b).
$600 \mathrm{mg} / \mathrm{kg} /$ gün asesülfam $\mathrm{K}$ uygulanan sıçanların testis dokularının 1şık mikroskobik incelemesinde, nispeten daha az sayıda tübülde dökülmeye bağlı vakuolize görünüm izlendi. Tübül lümenlerinde immatur spermatojenik hücre birikimi ile birlikte interstisyel alanda Leydig hücre sayısında azalma ve ödemin olduğu dikkati çekti (Şekil $3 c$ ve $3 d)$. 

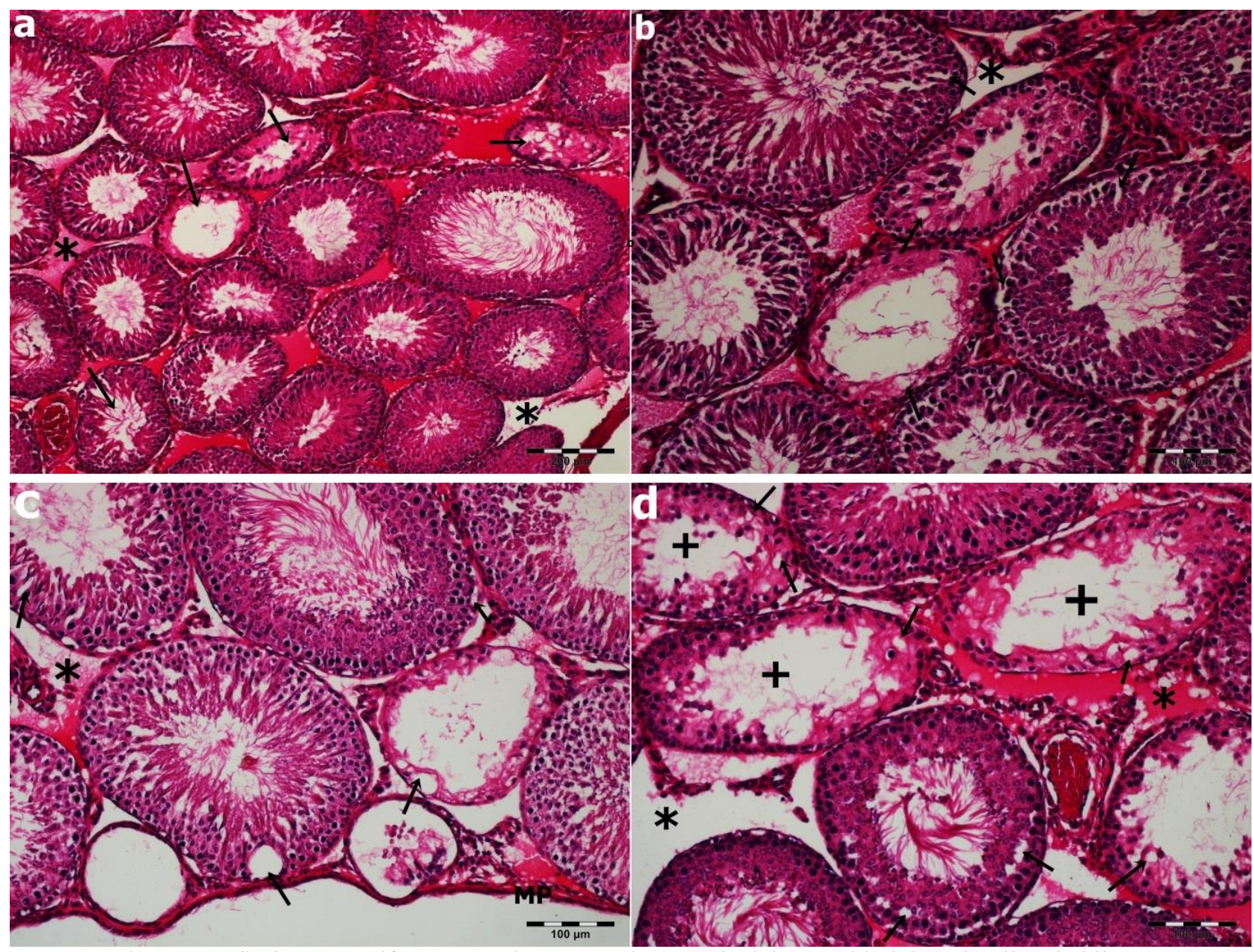

Şekil 3. (a-b) $300 \mathrm{mg} / \mathrm{kg} /$ gün asesülfam K uygulanan sıçanların testis doku örneklerinin 1şık mikroskobik görünümü. a) Bazı seminiferöz tübül lümenlerinin içlerinin boşalmış olduğu (oklar) ve insterstisyal ödemin varlığı $(*)$ görülmektedir. H\&E. Bar: $200 \mu \mathrm{m}$. b) Seminiferöz tübül epitelinde vakualizasyon (oklar) ile insterstisyel alanda ödem (*) görülmektedir. H\&E. Bar: $100 \mu \mathrm{m}$. (c-d) $600 \mathrm{mg} / \mathrm{kg} /$ gün asesülfam K uygulanan sıçanların testis doku örneklerinin ışık mikroskobik görünümü. c) Membrana propriada (MP) ve seminiferöz tübüllerde dejenerasyon, seminiferöz tübül epitelinde vakuolizasyon (oklar) izlenmektedir. H\&E. Bar: $100 \mu \mathrm{m}$ d) İçleri boşalmış seminiferöz tübüller (+), epitelde vakuolizasyon ve insterstisyal ödem (*) görülmektedir. H\&E. Bar: $100 \mu \mathrm{m}$

$300 \mathrm{mg} / \mathrm{kg} / \mathrm{gün}$ aspartam ve 300 $\mathrm{mg} / \mathrm{kg} /$ gün asesülfam $\mathrm{K}$ uygulanan sıçanların testis dokularının 1 şı mikroskobik incelemesinde, çok sayıda seminiferöz tübülde ve interstisyumda önemli dejeneratif değişiklikler izlendi. Seminiferöz tübül epitelinde vakuolizasyon görüldü. Bazı seminiferöz tübüllerin epitelinde dökülmeye bağlı olarak epitel kalınlığında azalma tespit edildi. Membrana proprianın kalın ve düzensiz bir hal aldığı görüldü. İnterstisyel alanda geniş boşlukların varlığı izlendi. İnterstisyel alanda yer alan Leydig hücrelerinin sayıca azaldıkları dikkati çekti (Şekil 4).

\section{Elektron mikroskobik bulgular}

Kontrol grubu sıçanlardan elde edilen testis doku örneklerinin elektron mikroskobik incelenmesinde, seminiferöz tübüller içerisinde yerleşen spermatojenik hücreler ve Sertoli hücreleri normal ince yapılarını korumaktayd1. Bazal lamina, miyoid hücreler ve membrana proprianın düzenli bir yapıda olduğu görüldü (Şekil 5).

$200 \mathrm{mg} / \mathrm{kg} /$ gün aspartam uygulanan siçanların testis doku örneklerinde membrana propriada düzensizlikler, spermatojenik hücreler arasında geniş boşluklar gözlenirken bütünlügünü koruyan Sertoli-Sertoli hücre bağlantıları, Sertoli-spermatojenik hücre bağlantıları ve spermatojenik hücreler arasında bozulmamış sitoplazmik köprüler dikkati çekti. Sertoli hücrelerinin sitoplazmasında mitokondriyon kristalarında hafif dejeneratif değişiklikler ile birlikte, lipofuksin granüller görüldü (Şekil 6a ve 6b). 


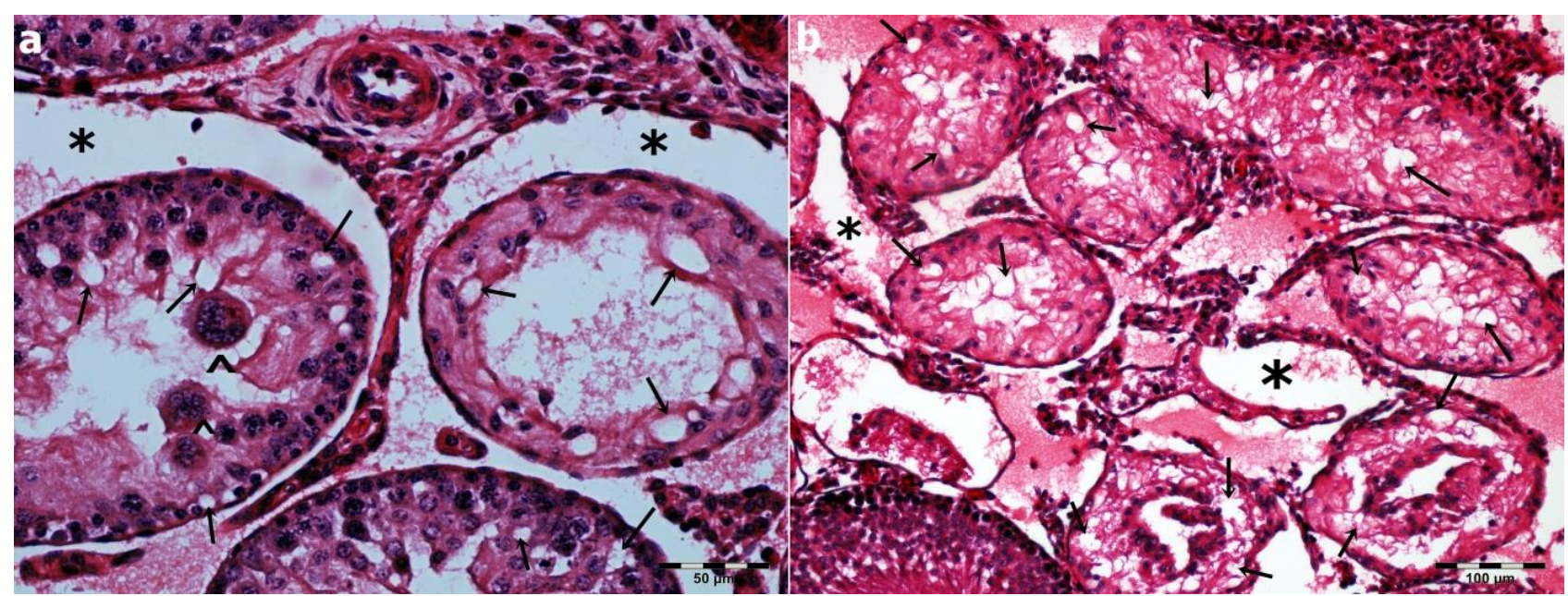

Şekil 4. $300 \mathrm{mg} / \mathrm{kg} /$ gün aspartam ve $300 \mathrm{mg} / \mathrm{kg} /$ gün asesülfam K uygulanan sıçanların testis doku örneklerinin 1şık mikroskobik görünümü. a) Seminiferöz tübül epitelinde vakuolizasyon (oklar) ve çok çekirdekli dev spermatojenik hücreler $\left(^{\wedge}\right)$ ile insterstisyal alanda ödem $\left(^{*}\right)$ görülmektedir. H\&E. Bar: $50 \mu \mathrm{m}$. b) Seminiferöz tübül epitelinin tamamen dejenere olduğu, yoğun vakuolizasyon (oklar) ve insterstisyal ödemin $\left(^{*}\right)$ varlığı dikkati çekti. H\&E. Bar: $100 \mu \mathrm{m}$.
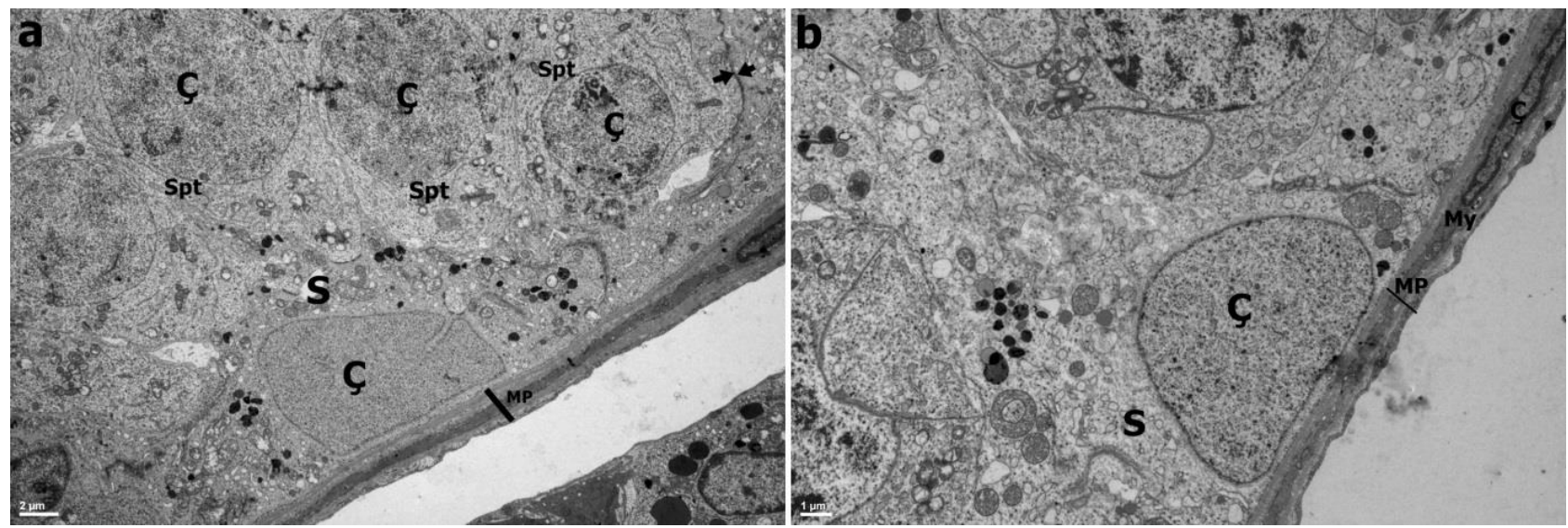

Şekil 5. Kontrol grubu testis doku örneklerinin elektron mikroskobik görünümü. a) membrana propria (MP), Sertoli hücresi (S), spermatosit (Spt), çekirdek (Ç) normal yapıda görülmektedir. Spermatojenik hücreler arasındaki sitoplazmik köprüler (oklar) izlenmektedir. Bar: $2 \mu \mathrm{m}$. b) Normal ince yapılarını korumuş olan Myoid hücre (My), membrana propria (MP), Sertoli hücre (S) çekirdeği (Ç) görülmektedir. Bar: $1 \mu \mathrm{m}$.

$300 \mathrm{mg} / \mathrm{kg} /$ gün aspartam uygulanan siçanların testis doku örneklerinin elektron mikroskobik incelemesinde seminiferöz tübülü saran membrana propriada kalınlaşma ve düzensizlikler görüldü. Sertoli hücrelerinin sitoplazmasında lipid damlacıklarında artış ve genişleme ile birlikte, elektron dens lipofuksin granülleri ve dejeneratif değişiklikler gösteren mitokondriyonlar ayırt edildi. Sertoli hücrelerinin sitoplazmasının geniş boşluklar dışında, genişlemiş agranüler endoplazmik retikülüm sisternaları nedeniyle vakuollü bir görünüm aldığı izlendi. Spermatid çekirdek zarlarında düzensizlikler dikkati çekti (Şekil 6c ve 6d).

$300 \mathrm{mg} / \mathrm{kg} / \mathrm{gün}$ asesülfam $\mathrm{K}$ uygulanan sıçanların testis doku örneklerinde membrana propriada nispeten kalınlaşma izlendi. Sertoli hücre sitoplazmasında dejenere ve genişlemiş mitokondriyonlar, artışmış fagositik cisimcikler, elektron dens lipofuksin granülleri ve dev lipid damlacıkları gözlendi. Ayrıca Sertoli hücre sitoplazmasında anormal SER vakuolizasyonu dikkati çekti. SertoliSertoli hücreleri arasındaki sıkı bağlantıların yer yer bütünlüklerini kaybettikleri belirlendi. Seminiferöz tübül lümeninde immatur hücrelere ve hücre artıklarına rastlandı (Şekil $7 \mathrm{a}$ ve $7 b)$.

$600 \mathrm{mg} / \mathrm{kg} /$ gün asesülfam $\mathrm{K}$ uygulanan sıçanların testis doku örneklerinin elektron mikroskobik incelemesinde membrana propria kalınlığında nispeten artış ve düzensizlikler görüldü. Sertoli hücre sitoplazmasında mitokondriyon kristalarında harabiyet, SER vakuolizasyonu, residüel cisimciklerde artış, lipid damlacıkları ve elektron dens lipofuksin granülleri gözlendi. 
Sertoli hücreleri ile spermatogonyumlar ve spermatojenik hücreler arasında geniş boşluklar dikkati çekti. Düzensiz çekirdek zarına sahip spermatojenik hücreler görüldü.
Seminiferöz tübül lümeninde immatur hücreler ve hücre artıkları izlendi (Şekil 7c ve 7d).
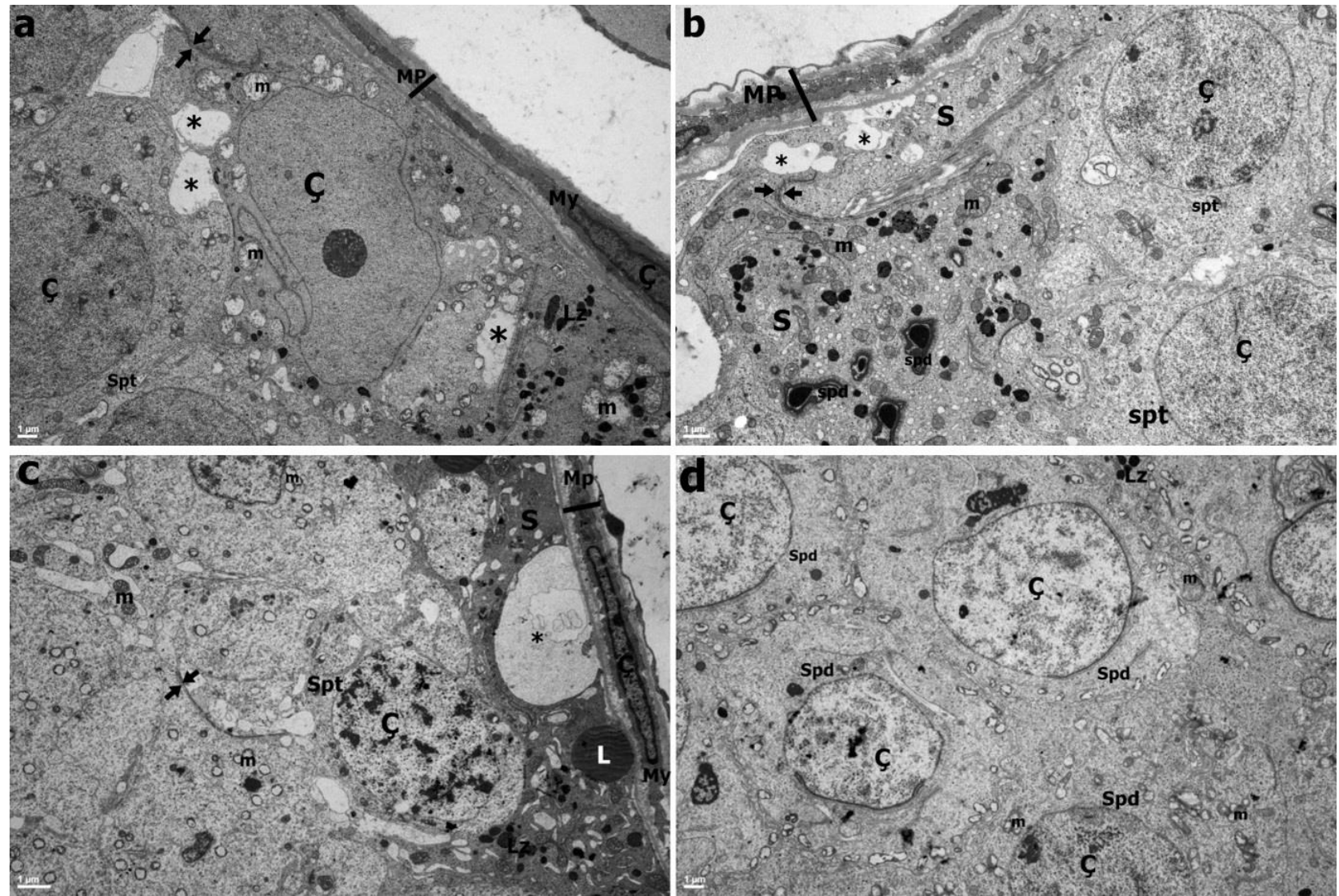

Şekil 6. (a-b) $200 \mathrm{mg} / \mathrm{kg} /$ gün aspartam uygulanan sıçanların testis doku örneklerinin elektron mikroskobik görünümü. a) Membrana propriada (MP) nispeten kalınlaşma, Sertoli hücre sitoplazmasında (S) vakuoller $\left(^{*}\right)$, mitokondriyonlarda (m) genişleme ve nispeten normal görünümde spermatositler (Spt) görülmektedir. Sertoli hücreleri arasındaki sık1 bağlantılar (oklar) izlenmektedir. Myoid hücre (My), Çekirdek (Ç). Bar: $1 \mu \mathrm{m}$. b) Kalın, kıvrıntılı bir membrana propria (MP) ve Sertoli hücre sitoplazmasında vakuoller $(*)$ ve spermatid (Spd) izlenmektedir. Mitokondriyonların (m) intakt halde kaldığı dikkati çekti. Spermatositlerin (Spt) kısmen normal yapılarını korudukları görülmektedir. Bar: $1 \mu \mathrm{m}$. (c-d) $300 \mathrm{mg} / \mathrm{kg} /$ gün aspartam uygulanan sıçanların testis doku örneklerinin elektron mikroskobik görünümü. c) Kalın bir membrana propria (MP) ile Myoid hücre (My) ve çekirdeği (Ç) izlenmektedir. Anormal vakuolizasyon $(*)$ ve lipid damlacığ 1 (L) içeren Sertoli hücreleri (S) görülmektedir. Spermatojenik hücreler arasında sitoplazmik köprüler (oklar) izlendi. Spermatositlerin (Spt) çekirdeğinde (Ç) kromatin yoğunlaşması ve sitoplazmada organel harabiyeti dikkati çekmektedir. Mitokondriyon (m). Bar: $1 \mu \mathrm{m}$. d) Bazı Spermatidlerin (Spd) sitoplazmalarında dejenerasyon ile birlikte çekirdekte $(C ̧)$ heterokromatin yamalarında artış görülmektedir. Mitokondriyon (m). Bar: $1 \mu \mathrm{m}$.

$300 \mathrm{mg} / \mathrm{kg} /$ gün aspartam ve 300 $\mathrm{mg} / \mathrm{kg} /$ gün asesülfam $\mathrm{K}$ uygulanan siçanların testis doku örneklerinde membrana propriada kalınlaşma ve tübül epitelinde apoptotik hücreler dikkati çekti. Ayrıca Sertoli hücrelerinin sitoplazmasında dejenere olmuş mitokondriyonlar, vakuoller, sayıca artmış lipofuksin granülleri ve lipid damlacıkları izlendi. Birçok tübülde Sertoli hücreleri arasındaki sıkı bağlantıların bozulduğu tespit edildi. Spermatojenik hücreler arasında geniş boşlukların yanı sıra seminiferöz tübül lümeninde immatur dejenere hücrelere rastlanıldı (Şekil 8).

\section{Tartışma}

Son y1llarda, toksik maddelerin neden olduğu infertilite oranındaki artış toplumlarda endişeye yol açmaktadır. Gıda katkı maddeleri ve beslenme şekli de bu toksik maddelerin vücuda girişinde önemli faktörlerdir ve erkeklerde üreme kapasitesini etkilemektedir. ${ }^{9}$

Yapay tatlandırıcılar, kalori alımını azaltırken lezzeti arttırmak için gıdalarda sükrozun yerini alan, besleyici olmayan gida katk1 maddesi sinıfindandirlar. ${ }^{5.10}$ Aspartam (L-aspartil-L-fenilalanin metil ester) ve 
asesülfam K, dünyada en popüler yapay tatlandırıcılar olarak karşımıza çıkmaktadır. ${ }^{10}$ Aspartam gıda, içecek, ilaç ve hijyen ürünleri dahil 6.000'den fazla üründe ve yaklașik 500 farmasötik üründe kullanılmaktadır. ${ }^{11}$ Farklı
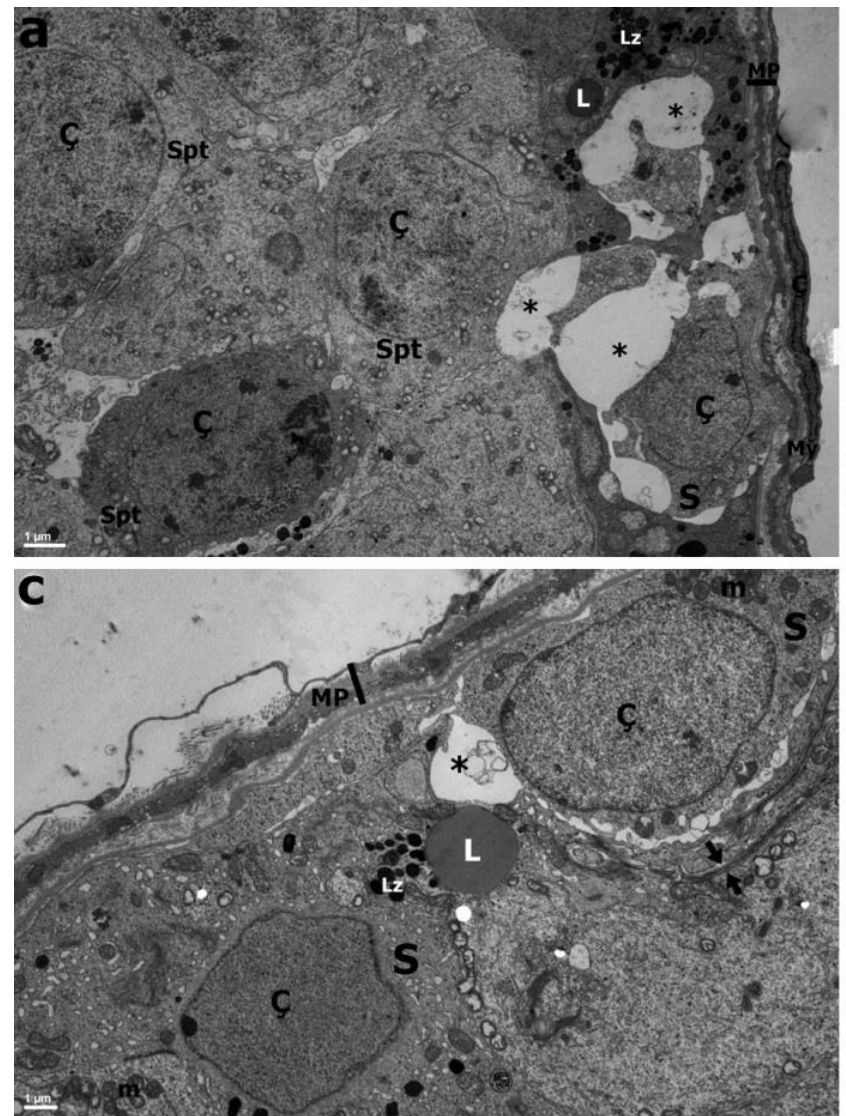

Şekil 7. (a-b) $300 \mathrm{mg} / \mathrm{kg} /$ gün asesülfam K uygulanan sıçanların testis doku örneklerinin elektron mikroskobik görünümü. a) Dejenere görünümde membrana propria (MP) ile çevrelenen seminiferöz tübüllerde Sertoli hücrelerinin (S) sitoplazmasında bol ve geniş vakuoller (*), agranüler endoplazmik retikülümun (SER) vakuolizasyonu, lipid damlacığ 1 (L) ve lizozomlar (Lz) izlenmektedir. Spermatositlerin (Spt) kısmen normal yapıda olduğu görülmektedir. Çekirdek (Ç), Myoid hücre (My). Bar: $1 \mu \mathrm{m}$. b) Sertoli hücrelerinin sitoplazmalarında (S) lipid damlacı̆̆ı (L) miktarında artış ve geniş vakuoller $(*)$ izlenmektedir. Mitokondriyon (m). Bar: $1 \mu$ m. Spermatositlerin sitoplazmalarında tübüler tip mitokondriyon (m) izlenmektedir. Çekirdek (Ç). Bar: $2 \mu \mathrm{m}$. (c-d) $600 \mathrm{mg} / \mathrm{kg} / \mathrm{gün}$ asesülfam K uygulanan sıçanların testis doku örneklerinin elektron mikroskobik görünümü. c) Membrana propria (MP) total kalınlığında artış ile birlikte Sertoli hücreleri (S) sitoplazmasında vakuoller (*), agranüler endoplazmik retikülüm (SER) sisternalarında genişleme, lipid damlacığı (L) ve lizozomlar (Lz) izlenmektedir. Çekirdek (Ç). Bar: $1 \mu \mathrm{m} . \mathrm{d})$ Kalın, kıvrıntılı bir membrana propria (MP) ile aşırı ve anormal vakuolizasyon (*) ve lipid damlacığı içeren Sertoli hücreleri (S) görülmektedir. Lizozom (Lz), Miyoid hücre (My), Çekirdek (Ç).Mitokondriyonlar (m) normal yapıdadır. Bar: $1 \mu \mathrm{m}$.

Uzun süreli yapay tatlandırıcı kullanımının fizyolojik fonksiyonları etkilediği bilinmekle birlikte, insanlar tercihen yapay tatlandirıcılar içeren sıfır veya düşük kalorili içecek ve yiyecekleri tüketmektedirler. ${ }^{2}$ Her ne kadar ABD Gıda ve İlaç Dairesi ve diğer düzenleyici kurumlar tarafından belirlenen kabul edilebilir günlük alım aralıklarında yapay tatlandırıcı tüketiminin sağlık açısından güvenli olduğu düşünülse de, günümüzde tatlandırıcıların güvenilirliği tartışmalıdır. Son yıllarda yapılan çalışmalarda, aspartam tüketiminin obezite, metabolik fonksiyonlarda bozukluklar ve bağırsak mikrobiyotasında değișiklikler gibi insan sağlı̆̆ı üzerine bazı olumsuz etkilere neden olabileceği gösterilmiştir. ${ }^{5}$ İnsanlar tarafindan tüketilen günlük aspartam miktarı giderek arttığından, aspartamın mevcut yan etkilerini kanıtlamak için daha fazla araştırma ve çalışma yapılması gerekmektedir. 

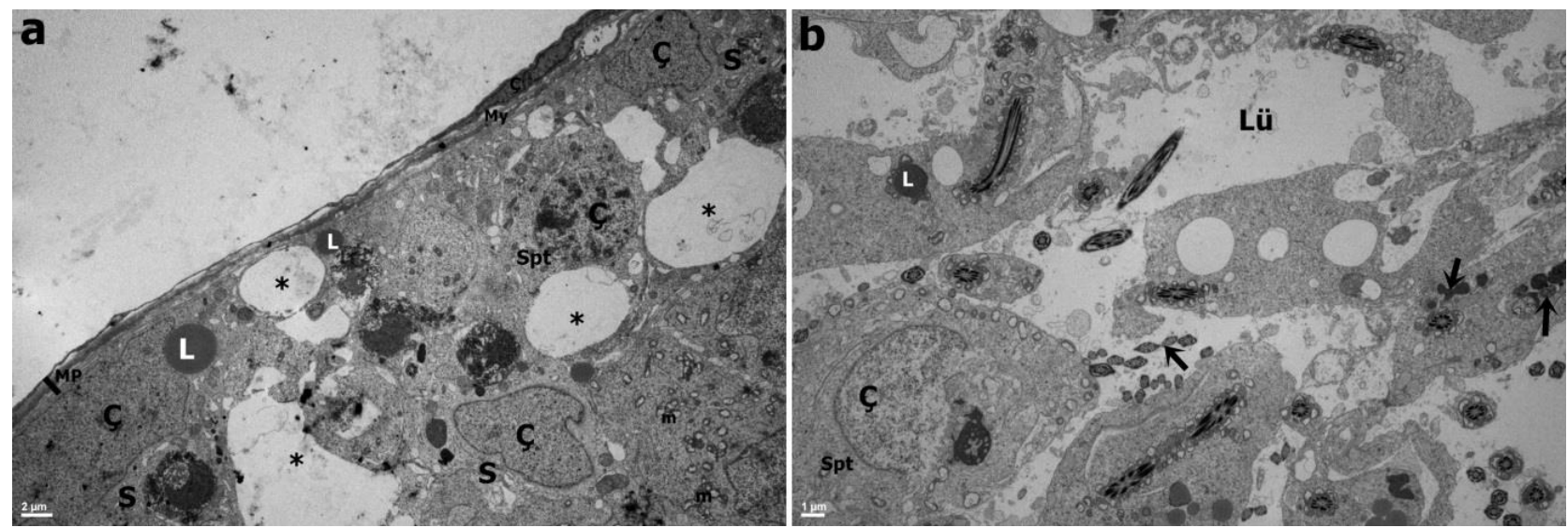

Şekil 8. $300 \mathrm{mg} / \mathrm{kg} /$ gün aspartam ve $300 \mathrm{mg} / \mathrm{kg} /$ gün asesülfam K uygulanan sıçanların testis doku örneklerinin elektron mikroskobik görünümü. a) Membrana propriada (MP) düzensizlik, Sertoli hücreleri (S) ve spermatositlerin (Spt) sitoplazmalarında ve aralarındaki vakuollerde $\left({ }^{*}\right)$ genişleme ve sayı artısı izlendi. Lipid damlacıkları (L), Myoid hücre (My), Çekirdek (Ç), Mitokondriyon (m). Bar: $2 \mu \mathrm{m}$. b) Lümende (Lü) immatür hücreler görülmektedir. Spermatositlerin (Spt) çekirdek (Ç) zarında düzensizlikler görüldü. Lümende fagositik atıklar (oklar) tespit edildi. Bar: $1 \mu \mathrm{m}$.

Bu çalışma, aspartam ve asesülfam K'nın erkek sıçanlarda üreme sistemi üzerindeki etkilerini değerlendirmek amaciyla yapılmıştır. Ülkemizde ve dünyada yaygın olarak kullanılan aspartam ve asesülfam K'nın, sıçan testis dokuları üzerindeki etkilerinin 1 şık ve elektron mikroskobik düzeyde araştırıldığı çalışmamızda; ayrı ayrı ve kombine aspartam ve asesülfam $\mathrm{K}$ kullanılmasının doza bağlı olarak testis dokusunda dejenerasyona yol açtı̆̆ 1 görülmüştür. Özellikle Sertoli hücrelerinde meydana gelen hasarın spermatogenez sürecinde sağlıklı spermatid oluşumunu engellediği izlenmiştir. Sağlıklı sperm oluşumundaki bu bozukluğun infertilite gibi ciddi sağlık problemleri ile sonuçlanabildiği bilinmektedir. Aspartam gastrointestinal sistemde fenilalanin, metanol ve aspartik aside ve ayrıca birçok dokuda formaldehit ve formik aside metabolize edilir. ${ }^{12}$ Fenilalanin normal vücut fonksiyonları için gerekli birçok aromatik bileşik ve vücut proteinleri için esansiyel bir prekürsördür. Ancak, diyetle yüksek fenilalanin alınmasının sıçanlarda karaciğer fenilalanin hidroksilaz aktivitesini baskıladığına dair çalışmalar vardır. ${ }^{6}$ Fenilalaninin in vivo etkileri henüz tam olarak açık değildir. Aspartik asit ise esansiyel olmayan bir amino asittir. Kemiricilerin yaklaşı $\% 20$ 'sinde aspartat veya glutamat ve bunların kombinasyon dozlarında (500 $\mathrm{mg} / \mathrm{kg}$ ) hipotalamik nekrozun histopatolojik belirtileri gözlenmiştir. Glutamat ve aspartamın eksitatör nörotransmiter gibi davrandıkları bilinmekle beraber bu moleküllerin patofizyolojik mekanizmaları tam olarak bilinmemektedir. Metanol, aspartamın moleküler ağırlığının \%10'unu oluşturan üçüncü önemli bileşenidir. ${ }^{13,14}$ Metanol, enterositlerde metabolize edilmez; hemen portal dolaşıma girer ve daha sonra karaciğerde formaldehite oksitlenir. Metanolün formaldehit ve formik aside metabolizmas1, süperoksit anyon ve hidrojen peroksit oluşumu ile ilişkilidir. Metanol oksidasyonu yoluyla oksidatif stresin gelişmesi, testislerin yerleştiği skrotal kesenin düşük sıcaklığını düzenleyen proteinlerde yapisal ve fonksiyonel bozukluklara neden olur. Sicaklıktaki hafif bir artış bile, protein denatürasyonunu indükleyerek spermatogenezde hizlı bozulmalara neden olabilir. ${ }^{9}$

Aspartam ve metabolitlerinin, amino asit metabolizması dahil olmak üzere çok çeşitli vücut süreçlerini potansiyel olarak bozduğu ve proteinlerin yap1 ve metabolizmasinı, nükleik asitlerin yapısal entegrasyonunu ve endokrin dengeleri etkilediği bildirilmiştir. ${ }^{15,16}$

Pek çok rapor, aspartamın toksik etkilerinin muhtemelen aspartam metabolizmasını takiben metanol oksidasyonu ile ilgili olduğunu bildirmiştir. Aspartam ve ardindan artan seviyelerde metanol, formaldehit ve formik asit almanın süperoksit anyon ve hidrojen peroksit oluşumu yoluyla mitokondriyal membrana zarar verebileceği, 
ROS artışı ve oksidatif strese yol açabileceği açıkça belirtilmiştir. ${ }^{17}$

Bugüne kadar yapılan çalışmalarda, yapay tatlandırıcı kullanımının vücuttaki farklı sistem ve organlar üzerindeki etkileri yoğun bir şekilde araştırılmıştır. 1980'den 2016'ya kadar aspartamın böbrek fonksiyonu üzerindeki olumsuz etkileri üzerine yapılan yayınlarda, uzun süreli aspartam tüketiminin böbrek dokusunda hasara neden olduğu ve serbest radikallerin üretimine yol açtığ gösterilmiştir. $^{5}$

Aspartam, Alzheimer, Parkinson, multipl skleroz gibi nörodejeneratif hastalıkların nedenlerinden biri olarak da gösterilmektedir. Ebtehak ve arkadaşlarının, aspartamın siyatik sinirin yapısı üzerindeki etkisini histolojik olarak araştırdıkları bir çalışmada, aspartamın siyatik sinirde histopatolojik değişikliklere neden olduğu gösterilmiştir. Çalışmada, erkek albino sıçanlara uzun süreli aspartam uygulamasının siyatik sinirin yapısı üzerinde dejeneratif bir etkisi olduğu görülmüştür. ${ }^{10}$ El-Ezaby ve arkadaşları yaptıkları bir çalışmada, yetişkin erkek albino sıçanlara mono sodyum glutamat (MSG) ve ASP'nin bir ay boyunca ayrı ayrı veya kombinasyon halinde oral yolla uygulamış ve bu maddelerin sıçanlarda hematolojik parametreler, lipid profili, karaciğer ve böbrek fonksiyonları üzerindeki etkilerini değerlendirmişlerdir. Aspartam ve MSG uygulanmasının, siçanların hematolojik parametrelerinde, lipid metabolizmas1, karaciğer ve böbrek fonksiyonlarında bozulmalara neden olduğunu bildirmişlerdir. Araştırmacılar, insanları bu katkı maddelerinden korumak için gıda ürünlerinin bileşenlerine daha fazla dikkat edilmesi gerektiği kanaatine varmışlardır. ${ }^{18}$ Choudhary AK ve arkadaşları, uzun süre aspartam tüketiminin bağışıklık sistemiyle ilişkili organlarda hem mRNA transkript hem de protein ekspresyon seviyelerinde hsp70, bcl-2 ve bax ekspresyonu üzerinde herhangi bir etkisi olup olmadığını araştırılmışlardır. 90 gün boyunca aspartamin oral yoldan uygulanmasının, hayvanların bağışıklık sistemiyle ilişkili organlarında belirgin bir DNA fragmantasyonuna neden olmadığ tespit edilmiş; bununla birlikte, kontrole kıyasla aspartam verilen hayvanlarda hem mRNA transkript hem de protein ekspresyon seviyesinde bcl-2 ve bax ekspresyonundaki önemli değişiklik dişında hsp70 ekspresyonunda da önemli bir artış olduğu görülmüştür. Araştırmacılar, aspartam metabolitlerinin neden olduğu oksidatif hasara cevap olarak hsp70 seviyesinin arttığını; bununla birlikte, bu metabolitlerin bağışıklık sistemiyle ilişkili organlarda apoptozu indüklediği kanaatine varmışlardır. Ancak, tüm bu bulguların ortaya çıkmasında rolü olan moleküler mekanizmaları açıklamak için ayrıntılı çalışmalara ihtiyaç vardır. ${ }^{19}$ Gong ve arkadaşları, erkek ICR farelerine oral yoldan verilen yapay bir tatlandirıcı olan sakarin sodyumun testis fonksiyonları üzerindeki etkilerini araştırmışlardır. Orta ve düşük doz sakarin ile tedavi edilen gruplarda fare vücut ağırlıkları ve testis ağırlıklarının $\operatorname{arttığ1}$ ve testiste yer alan tat moleküllerin (T1R3 ve Galpha) ekspresyonlarının arttığ görülmüştür. Yüksek sakarin konsantrasyonlarına maruz kalmanın testosteron seviyelerinde azalmaya yol açtığ ve spermatogenezi önemli ölçüde bozduğu tespit edilmiştir. Sonuçlar, sakarine bağlı fizyolojik etkilerin testiste bulunan tat molekülleri (T1R3 ve Galpha) üzerinden etkili olduğunu göstermektedir. $\mathrm{Bu}$ nedenle araştırmacılar, günlük yaşamda yapay tatlandirıcıların potansiyel yan etkileri göz önüne alındığında bunların aşırı kullanımının yeniden değerlendirilmesi ve toksik etkileri konusunda daha fazla araştırma yapılması gerektiğini rapor etmişlerdir. ${ }^{20}$ Bizim çalışmamızda ise yapay tatlandırıcılar olan aspartam ve asesülfam K'nın ayrı ayrı ve birlikte sıçan testis dokusu üzerindeki etkileri 1ş1k ve elektron mikroskobik düzeyde ilk defa araştırılmıştır. Çeşitli çalışmalarda, testis dokusunun histomorfometrik parametrelerinin değerlendirilmesi, bu organa verilen hasarın boyutunu değerlendirmek için uygun bir yaklaşım olarak kabul edilmektedir. ${ }^{21,22} \mathrm{Bu}$ çalışmada, sekiz hafta boyunca 200 $\mathrm{mg} / \mathrm{kg} /$ gün ve $300 \mathrm{mg} / \mathrm{kg} /$ gün aspartam uygulanan sıçanların testis doku örneklerinde doza bağl1 olarak artan dejenerasyonlar dikkati çekmiştir. Histolojik gözlemlerimiz, aspartamın doza bağlı bir şekilde seminiferöz epitelde düzensizliği artırabileceğini ve 
interstisyel bağ dokusunda şiddetli ödem oluşturabileceğini ortaya koymuştur. Bizim çalışmamıza benzer şekilde, Anbara ve arkadaşları da, yüksek doz aspartam uygulamasının testislerde şiddetli morfolojik değişikliklere neden olduğunu göstermişlerdir. Germ hücrelerinin sayısında ciddi azalma ve yoğun immün hücre infiltrasyonu, ödematöz sıvı birikimi, atrofiye uğramış seminiferöz tübüllerin varlığını ve Sertoli hücrelerinin germ hücreleriyle bağlantılarını kaybettiklerini gözlemlemişlerdir. Araştırmacılar, uzun süreli aspartam tüketiminin, oksidatif stresin indüksiyonu yoluyla erkek farelerde üreme hasarına neden olduğu kanaatine varmışlardır. ${ }^{9}$ Çalışmamızda, sekiz hafta boyunca $300 \mathrm{mg} / \mathrm{kg} /$ gün ve $600 \mathrm{mg} / \mathrm{kg} /$ gün asesülfam $\mathrm{K}$ uygulanan sıçanların testis doku örneklerinde Sertoli hücrelerinde dejenerasyonlar ve spermatojenik hücre yapılarında düzensizlikler görülmüştür. Sekiz hafta boyunca $300 \mathrm{mg} / \mathrm{kg} /$ gün aspartam ve $300 \mathrm{mg} / \mathrm{kg} /$ gün asesülfam $\mathrm{K}$ uygulanan sıçanların testis doku örneklerinde ise membrana propriada kalınlaşma ve tübül epitelinde apopitotik hücreler dikkati çekmiştir. Ayrıca Sertoli hücrelerinin sitoplazmasında dejenere ve genişlemiş mitokondriyonlar, sayıca artmış lipofuksin granülleri ve lipid damlacıkları izlendi. Spermatojenik hücreler arasında geniş boşlukların yanı sıra seminiferöz tübül lümeninde immatur dejenere hücreler tespit edilmiştir. Aspartam ve asesülfam K'nın doza bağlı olarak testis hücresel yapısında yol açtığ 1 bu dejenaratif değişiklikler infertilite ile sonuçlanabilmektedir. Bu nedenle günümüzde oldukça yaygın hale gelen erkek infertilitesinde yapay tatlandırıcı kullanımının rolüyle ilgili daha fazla araştırma yapılması gerekmektedir.

\section{Sonuç}

Sunulan çalışma, yapay tatlandırıcıların hücresel yapıya olan etkilerini gösteren ilk çalışma olması sebebiyle önemlidir. Bununla birlikte aspartam ve asesülfam K'nın derinlemesine etkilerini değerlendirmek için daha ileri çalışmalara ihtiyaç vardır. Yapay tatlandırıcıların erkek üreme sistemindeki toksisitesinin doğrulanması, daha kapsamlı deneysel çalışmaların yanı sıra klinik araştırmalar yapılmasını gerektirmektedir.

\section{Araştırmanın Etik Boyutu}

Araştırmanın yapılabilmesi için ilgili üniversitenin Sağlık Bilimleri Deneysel Araştırma Merkezi'nden Etik kurul onayı alınmıştır (Tarih: 08.02.2009: no:4).

\section{Yazar Katkıları}

Veri toplama, veri işleme, analizlerin yapılması ve yorumlanması L.S. tarafindan yapılmıştır. Araştırmanın konsepti, dizaynı, literatür tarama ve makalenin yazımı L.S. ve Y.K. tarafından yapılmıştır.

\section{Çıkar Çatışması Beyanı}

$\mathrm{Bu}$ çalışmada yazarlar arasında çıkar çatışması bulunmamaktadır.

\section{Araştırma Desteği}

Araştırma için hiçbir kurumdan destek alınmamıştır.

\section{Hakem Değerlendirmesi}

Diş bağımsız.

\section{Kaynakça}

1. Solomi L, Rees GA, Redfern KM.The acute effects of the nonnutritive sweeteners aspartame and acesulfame-K in UK diet cola on glycaemic response. International Journal of Food Sciences and Nutrition. 2019;70(7): 894-900.

2. Ibi D, Suzuki F, Hiramatsu M. Effect of AceK (acesulfame potassium) on brain function under dietary restriction in mice. Physiology \& Behavior. 2018; 188:291-97.

3. Marinovich M, Galli CL, Bosetti C, Gallus S, La Vecchia C. Aspartame, low-caloriesweeteners and disease: regulatorysafety and epidemiological issues. Food and Chemical Toxicology. 2013;60:109-15.

4. Yılmaz S, Uçar A. A review of the genotoxic and carcinogenic effects of aspartame: does it safe or not? Cytotechnology. 2014;66:875-81.

5. Ardalan MR, Tabibi H, Attari VE, Mahdavi AM. Nephrotoxic Effect of Aspartame as an Artificial Sweetener. Iranian Journal of Kidney Diseases. 2017;11(5): 339-43.

6. Alkafafy ME, Ibrahim ZS, Ahmed M, El-Shazly SA. Impact of aspartame and saccharin on the rat liver: Biochemical, molecular, and histological approach. International Journal of Immunopathology and Pharmacology. 2015;28(2):247-55.

7. Ashok I, Poornima PS, Wankhar D, Ravindran R, Sheeladevi R. Oxidative stress evoked damages on rat sperm and attenuated antioxidant status on consumption of aspartame. International Journal of Impotence Research. 2017;29:164-70.

8. Mukhopadhyay M, Mukherjee A, Chakrabartı J. In Vivo Cytogenetic Studies on Blends of Aspartame and AcesulfameK. Food and Chemical Toxicology. 1998;38(2000):75-7.

9. Anbara H, Sheibani MT, Razi M. Long-Term Effect of Aspartame on Male Reproductive System: Evidence for Testicular Histomorphometrics, Hsp70-2 Protein Expression and Biochemical Status. International Journal of Fertility and Sterility. 2020;14(2):91-101.

10. Hassen EZ, Mahmoud AA, Ibrahem NE, El-Shal AS. The Effect of Long Term Administration of Aspartame on the Sciatic nerve of adult male albino rats and the Possible Therapeutic Role of Ozone (Histological and Biochemical 
Study). The Egyptian Journal of Histology. 2019;42(1):191201.

11. Mallikarjun S, Sieburth RM. Aspartame and Risk of Cancer: A Meta-analytic Review. Archives of Environmental \& Occupational Health. 2013;70(3):133-41.

12. Shalabya AM, Ibrahima MAAH, Aboregela AM. Effect of aspartame on the placenta of adult albino rat. A histological and immunohistochemical study. Annals of Anatomy. 2019;224: $133-41$.

13. Potenza DP, El-Mallakh RS. Aspartame-Clinical update. Connecticut Medicine. 1989; 53:395-400.

14. Baydar T, Şahin G. Aspartam Metabolizması ve Toksisitesi. Türkiye Klinikleri Tip Bilimleri Dergisi. 1997;17(3):141-52.

15. Oyama Y, Sakai H, Arata T, Okano Y, Akaike N, Sakai K, et al. Cytotoxic effects of methanol, formaldehyde, and formate on dissociated rat thymocytes: a possibility of aspartame toxicity. Cell Biology Toxicology. 2002;18(1):43-50.

16. Trocho C, Pardo R, Rafecas I, Virgili J, Remesar X, FernandezLopez JA, et al. Formaldehyde derived from dietary aspartame binds to tissue components in vivo. Life Sciences. 1998; 63(5): $337-49$.

17. Ashok I, Poornima PS, Wankhar D, Ravindran R, Sheeladevi R. Oxidative stress evoked damages on rat sperm and attenuated antioxidant status on consumption of aspartame. International Journal of Impotence Research. 2017; 29(4): 164-70.

18. El-Ezaby MM, Hamide NA, Marwa AE, El-Maksoud A, Shaheen EM, Embashi MR. Effect of some food additives on lipid profile, kidney function and liver function of adult male albino rats. Journal of Basic and Environmental Sciences. 2018;5:52-9.

19. Choudhary AK, Devi RS. Effects of aspartame on hsp70, bcl-2 and bax expression in immune organs of Wistar albino rats. The Journal of Biomedical Research. 2016;30(5):427-35.

20. Gong T, Wei Q, Mao D, Nagaoka K, Watanabe G, Taya K, Shi F. Effects of Daily Exposure to Saccharin and Sucrose on Testicular Biologic Functions in Mice. Biology of Reproduction. 2016; 95(6): 1-13.

21. Asri-Rezaei S, Nourian A, Shalizar-Jalali A, Najafi G, Nazarizadeh A, Koohestani M, et al. Selenium supplementation in the form of selenium nanoparticles and selenite sodium improves mature male mice reproductive performances. Iran Journal of Basic Medical Sciences. 2018;21(6):577-85.

22. Anbara H, Shahrooz R, Razi M, Malekinejad H, Najafi G. The effect of vitamin $\mathrm{C}$ on mice hemolytic anemia induced by phenylhydrazine: an animal model study using histological changes in testis, preimplantation embryo development, and biochemical changes. Iran Journal of Basic Medicine Sciences. 2018; 21(7):668-77 